\title{
KONSEP PEMBARUAN SISTEM PENDIDIKAN ISLAM MENURUT MUHAMMAD ‘ABDUH
}

\author{
Supriadi AM. \\ Sekolah Tinggi Agama Islam Asy-Syukriyyah \\ JL KH. Hasyim Ashari, KM 3, Cipondoh, Poris Plawad Indah, 15141, Kota Tangerang, Banten \\ Email: supriadi@gmail.com
}

\begin{abstract}
The Concept of Reformation of Islamic Educational System According to Muhammad Abduh. Muhammad 'Abduh is not only a well-known interpreter of al-Qur'an and reformer of Islamic paradigm, but he is also known for his thought in education. The reformation of education in Egypt which pioneered by Muhammad Ali gave enormous contribution to the modern world. His reform movement has introduced Western science and technology to the Muslims, until it comes the time that removes the black cloud enveloping the mindset and religious attitude of the Muslims, thus was born the intelligent Muslims who have broader religious knowledge. The characteristic of the educational thought of Muhammad Abduh leans on progressive flow. This educational reformation continued by Muhammad Abduh, especially by reforming educational elements such as educational goals, educators, students, and teaching methods.
\end{abstract}

Keywords: Reformation, Education, Thought

Abtrak: $\quad$ Konsep Pembaharuan Sistem Pendidikan Islam Menurut Muhammad Abduh.
Muhammad Abduh selain terkenal dalam bidang penafsiran al-Qur'an dan
pembaharu pewmikiran Islam, ternyata juga dikenal pemikirannya dalam
bidang pendidikan. Pembaruan pendidikan di Mesir yang pelopori oleh
Muhammad Ali sangat besar kontribusinya untuk menjadi negara modern.
Gerakan pembaruannya telah memperkenalkan ilmu pengetahuan dan
teknologi Barat kepada umat Islam, dan sampai suatu waktu dapat me-
nyingkap awan hitam yang menyelimuti pola pikir dan sikap keagamaan
sehingga lahirlah intelegensi muslim yang berpengetahuan agama yang
luas. Corak pemikiran pendidikan Muhammad Abduh cenderung pada
aliran progresif. Pembaharuan Pendidikan itulah yang dilanjutkan oleh
Muhammad Abduh, terutama dengan memperbaharui unsur-unsur
pendidikan yaitu, tujuan pendidikan, pendidik, murid, dan metode
pembelajaran.

Kata kunci: Pembaruan, Pendidikan, Pemikiran 


\section{Pendahuluan}

Kehidupan Umat Islam dilihat dari perspektif sejarah, mengalami pasang surut, naik turun dan bergelombang. Menurut Harun Nasution, ${ }^{1}$ secara garis besarnya sejarah Islam dibagi ke dalam tiga periode besar, yaitu periode klasik, periode pertengahan, dan periode modern.

Periode klasik (650-1250 M) merupakan zaman kemajuan Islam, zaman ini terbagi ke dalam dua fase, yaitu fase ekspansi, integrasi dan puncak kemajuan. Pada fase ekspansi, integrasi dan puncak kemajuan, daerah Islam meluas melalui Afrika Utara sampai Spanyol di Barat dan melalui Persia sampai ke India di Timur. Pada masa inilah berkembang dan memuncak ilmu pengetahuan, baik dalam bidang agama maupun dalam bidang non-agama, dan juga bidang kebudayaan Islam.

Lalu datang periode modern yang dimulai pada tahun 1800 M. Periode ini, menurut para ahli sejarah, disebut sebagai zaman kebangkitan umat Islam. Jatuhnya Mesir ke tangan Barat menginsafkan dunia Islam akan kelemahannya dan menyadarkan umat Islam bahwa di Barat telah muncul peradaban baru yang lebih tinggi dan merupakan ancaman baru bagi Islam.

Bahwa dari waktu ke waktu selalu ada usaha-usaha pembaharuan, atau penyegaran atau pemurnian umat Islam terhadap agamanya menurut pendapat Nurcholish Madjid, ${ }^{2}$ itu merupakan sesuatu yang telah menyatu dengan sistem Islam dalam sejarahnya. Hal demikian tampak sejalan dengan penegasan Nabi Muhammad dalam sebuah haditsnya yang mengisyaratkan hal tersebut:

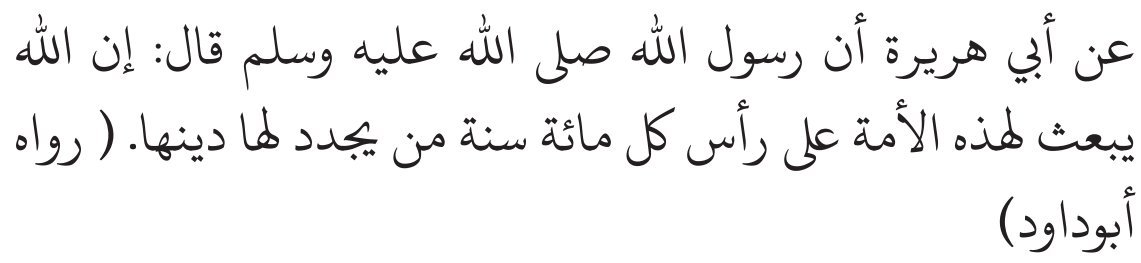

Sesungguhnya Allah SWT. akan mengutus seorang pembaru (mujaddid) untuk umat Islam pada setiap penghujung seratus tahun supaya ia memperbarui ajaran-ajaran agama mereka. ${ }^{3}$

\footnotetext{
${ }^{1}$ Harun $\quad$ Nasution, Pembaharuan dalam Islam, (Jakarta: Bulan Bintang, 1975), h. 12.

${ }^{2}$ Nurcholis Majid, Islam Doktrin dan Peradaban, (Jakarta: Paramadina, 2000), h. 449.

${ }^{3}$ Hadits Riwayat Abu Dawud, Sunan Abi Dâwûd, (Beirut: Dâr al-Kutub al-'ilmiyyah,1996), Juz III, h. 424.
} 
Modernisme Islam atau pembaharuan dalam Islam selama ini dipahami sebagai upaya untuk menyesuaikan paham-paham keagamaan Islam dengan dinamika dan perkembangan baru yang timbul atau ditimbulkan oleh kemajuan ilmu pengetahuan dan teknologi medern. Atau, yang dimaksud dengan modernisme Islam adalah upaya memperbarui penafsiran, penjabaran, dan cara-cara pelaksanaan ajaran-ajaran dasar dan petunjuk- petunjuk yang terdapat dalam al-Quran dan al-Hadits sesuai dan sejalan dengan perkembangan situasi dan kondisi masalah yang dihadapi. Dengan demikian pembaharuan Islam bukanlah suatu upaya yang ringan tetapi ia menjadi suatu tuntutan yang penting untuk menghentikan proses degenerasi umat Islam dalam semua segi kehidupan dan untuk menutup dan mempersempit kesenjangan antara Islam dalam teori dan Islam dalam praktek.

Dalam sejarah perkembangan pembaharuan Islam terdapat suatu gagasan utama yang selalu dicetuskan oleh para tokoh pembaru, yaitu pembaharuan dalam bidang pendidikan. Wajar, Pendidikan diakui sebagai kekuatan yang dapat membantu masyarakat mencapai kemajuan peradaban. Bahkan tidak ada satu prestasi pun tanpa peranan pendidikan.

Dalam ajaran Islam, pendidikan mempunyai kedudukan yang mulia. Hal ini bisa dilihat dalam al-Quran dan al-Hadits yang banyak menjelaskan tentang arti pendidikan bagi kehidupan umat Islam sebagai hamba Allah. Dalam al-Quran ditegaskan bahwa Allah menciptakan manusia agar menjadikan tujuan akhir atau hasil segala aktifitasnya sebagai pengabdiannya kepada Allah. ${ }^{4}$ Aktifitas yang dimaksudkan oleh Allah tersimpul dalam ayat-ayat al-Quran yang menegaskan bahwa manusia adalah khalifah Allah. ${ }^{5}$ Tugas manusia sebagai khalifah dapat dilaksanakan dengan baik, jika dibekali dengan pengetahuan, keterampilan, dan kepribadian luhur yang sesuai dengan kehendak Allah. Semua ini dapat dipenuhi hanya melalui proses pendidikan.

Gagasan tentang pembaharuan pendidikan di Mesir bermula ketika invasi Napoleon ke Mesir dengan membawa ahli-ahli ilmu pengetahuan membuka tabir bagi mereka untuk mengetahui keindahan Mesir dengan peradaban, kebudayaan, dan sosialnya. Napoleon melihat bahwa Mesir

\footnotetext{
${ }^{4}$ QS. Al- Dzariyât, [51]: 56.

${ }^{5}$ QS. al- Baqârah, [2]: 30, dan Hûd, [11]: 61.
} 
perlu diletakkan di bawah kekuasaan Perancis. ${ }^{6}$ Dengan berbagai cara Napoleon dapat mengalahkan kaum Mamluk dan Mesir dapat dikuasai. Pendudukan Mesir oleh Napoleon Bonaparte adalah merupakan tonggak sejarah bagi umat Islam untuk mendapatkan kembali kesadaran akan kelemahan dan keterbelakangan mereka. Ekspedisi Napoleoan tersebut bukan hanya menunjukkan akan kelemahan umat Islam, tetapi juga sekaligus menunjukkan kebodohan mereka. Ekspedisi Napeleon tersebut di samping membawa sepasukan tentara yang kuat, juga turut serta dalam ekspedisi itu 500 kaum sipil pria dan 500 kaum wanita. Di antara kaum sipil tersebut terdapat 167 ahli dalam berbagai cabang ilmu pengetahuan. Napoleon juga membawa seperangkat peralatan ilmiah, untuk mengadakan penelitian di Mesir.

Kontak orang Mesir, terutama pejabat dan ulamanya membuka mata kaum muslimin akan kelemahan dan keterbelakangannya, sehingga akhirnya timbul berbagai macam usaha pembaharuan dalam segala bidang kehidupan, untuk mengejar ketinggalan dan keterbelakangan mereka, termasuk usaha-usaha di bidang pendidikan.

Menurut tokoh-tokoh pembaharu Islam, salah satu penyebab kemunduran umat Islam adalah melemah dan merosotnya kualitas pendidikan Islam. Untuk itu, perlu mengembalikan kekuatan pendidikan Islam sebagai penyangga kemajuan umat Islam, sehingga bermunculanlah gagasangagasan tentang pembaharuan pendidikan Islam yang diikuti dengan pelaksanaan perubahan penyelenggaranya

Muhammad Abduh adalah salah seorang yang menempati posisi penting dalam konstalasi gerakan pembaharuan Islam. Abduh, adalah seorang yang disebut-sebut sebagai salah seorang tokoh pembaru Islam yang menjadikan pendidikan sebagai prioritas utamanya. Abduh dalam upaya mereformulasi Islam lebih menekankan pada aspek keagamaan dari pada politik. Reformulasi Islam yang dikembangkan Abduh adalah: pertama dengan mengadakan distingsi antara yang esensial dan kedua mempertahankan aspek fundamental dan meninggalkan aspek aksidental warisan sejarah Islam.

Dengan memperhatikan posisinya sebagai seorang tokoh pembaru yang terkemuka, perhatiannya dan kecintaannya terhadap ilmu

${ }^{6}$ Harun Nasution, Pembaharuan dalam Islam, h. 28. 
pengetahuan, maka tulisan ini akan menguak aspek pembaharuan yang dikembangkan Muhammad Abduh.

\section{Pendidikan dan Intelektualitas Muhammad 'Abduh}

Nama lengkapnya adalah Muhammad bin Abduh bin Hasan Khairullah. Dilahirkan di desa Mahallat Nasr di Kabupaten al-Buhairah, Mesir pada tahun 1849 M.7 Ibunya masih mempunyai silsilah keturunan pemimpin besar Islam yaitu Umar bin Khattab. Orang tuanya pemeluk agama yang taat pada ajaran Islam, sehingga merekapun mendidik anaknya dengan ajaran Islam yang ketat. ${ }^{8}$

Pendidikan Muhammad 'Abduh dimulai dengan belajar menulis dan membaca di rumah. Kemudian ia menghafal al-Quran selama masa dua tahun di bawah bimbingan seorang guru sehingga pada usianya yang 12 tahun 'Abduh telah hafal al-Quran seluruhnya.'

Ia kemudian diserahkan oleh orang tuanya untuk belajar di masjid al-Ahmadi di Tantha. Di sana 'Abduh diajarkan pelajaran tajwid alQuran, bahasa Arab, nahwu, sharaf, fiqh, dsb. Setelah sekian lama belajar disana, ia merasa sistem pengajarannya membosankan sehingga muncul ketidakpuasan. Pada pengalamannya itu beliau mengatakan:

"Satu setengah tahun saya belajar d imesjid Syekh Ahmad dengan tidak mengerti satu apapun. Ini adalah karena metodenya yang salah, guruguru mulai mengajak kita dengan menghafal istilah-istilah tentang nahwu dan fiqh yang kita tidak ketahui artinya. Guru-guru tak merasa penting apa yang kita mengerti atau tidak."

Karena ketidakpuasannya itu, beliau akhirnya meninggalkan masjid tersebut dan pulang ke desanya dengan niat untuk bekerja sebagai petani. Pada usianya yang ke 16 ia menikah dan empat puluh hari dari umur perkawinannya, ayahnya menyuruh beliau kembali ke Thantha untuk belajar. Kemudian beliau ke rumah salah seorang pamannya yang bernama Syekh Darwisy. ${ }^{10}$ Beliau adalah seorang perantau yang pernah pergi keluar Mesir untuk belajar agama Islam, sehingga beliau menjadi seorang yang

\footnotetext{
${ }^{7}$ Rasyid Ridha, Tafsîr al-Manâr, (Beirut: Dar al-Kutub al-Ilmiah, 1999), h. 4.

${ }^{8}$ Rasyid Ridha, Tafsîr al-Manâr,. h. 4.

${ }^{9}$ Qadri Qal'aji, Tsalatsatun min 'a'lam al-Hurriyah, (Beirut: Binayatul Wahhad, 1993), h. 166.

${ }^{10}$ Yusuf Hamadi, al-Imâm Muhammad Abduh, (Mesir: Maktabah Misr,), h. 11.
} 
berpengetahuan luas khususnya mengenai ajaraan-ajaran Islam.

Kepada 'Abduh, beliau banyak memberikan semangat untuk belajar, membaca buku, mulanya 'Abduh enggan menerima saran itu. Namun, berkat usaha pamannya itu telah berhasil merubah pandangan 'Abduh dari seorang yang membenci ilmu pengetahuan menjadi seorang yang gemar membaca dan mencintai ilmu pengetahuan. Sejak saat itulah minat bacanya mulai tumbuh, dan ia berusaha membaca buku-buku secara mandiri. Istilah-istilah yang tidak dipahaminya ia tanyakan kepada pamannya. Tentang pengalamannya itu beliau mengatakan:

"Tidaklah berlalu lima hari dari masa pertemuan itu, kecuali apa yang tadinya paling kusenangi seperti bermain, bercanda, dan berbanggabangga telah berubah menjadi hal-hal yang paling kubenci".

Setelah selesai belajar di Tantha 'Abduh meneruskan studinya ke alAzhar, tetapi 'Abduh kembali merasa kecewa sebagaimana di Tantha. Ia memandang metode pengajarannya membosankan, beku dan dogmatis. Dia menyerang cara kajian buku-buku di al-Azhar, yang lebih banyak ditujukan untuk membahas tafsiran-tafsiran orang dari pada teks aslinya. Hatinya tergugah untuk menghilangkan belenggu pemikiran. ${ }^{11}$

Kekecawaan muncul kembali pada diri Muhammad 'Abduh dan beliau hampir saja kehilangan semangat hidup, tetapi pada tahun 1286 $\mathrm{H}$, beliau bertemu dengan Jamaluddin al-Afgani ${ }^{12}$ seseorang yang terkenal didunia Islam sebagai seorang mujtahid, mujaddid. Bersama-sama dengan teman-temannya, Muhammad 'Abduh belajar dan berdiskusi dengan tokoh pemimpin tersebut. Walau mereka harus mendapatkan tantangan keras dari para ulama dan sebagian besar mahasiswa al-Azhar. Karena mempelajari ilmu kalam dan filsafat, menurut persepsi mereka dapat menggoncangkan iman. Dalam hal ini ia pernah dipanggil menghadap Syaikh 'Alaisy, karena ketertarikannya pada teologi Mu'tazilah. Ketika ditanya apakah benar ia telah memilih aliran Mu'tazilah dan meninggalkan aliran Asy'ariyah, ia dengan tegas menjawab, “jika saya tidak bertaklid kepada Asy’ari, mengapa saya mesti bertaklid kepada Mu'tazilah. Hal ini menunjukkan Muhammad Abduh bukan saja tidak mengikatkan dirinya pada suatu aliran manapun,

\footnotetext{
${ }^{11}$ Maryam Jameelah, Islam dan Modernisasi, (Surabaya: Usaha Nasional, 1981), h. 180.

${ }^{12}$ Harun Nasution, Muhammad Abduh dan Teologi Rasional Mu'tazilah, (Jakarta: Universitas Indonesia, 1987), h. 13.
} 
tetapi juga sejak mahasiswa telah mampu menunjukkan sikapnya yang kritis dan menentang taklid.

Dengan sikap kritis itulah Muhammad 'Abduh menjalani studi di alAzhar. Pada tahun 1877 Muhammad 'Abduh lulus dari al-Azhar dengan gelar âlim. Dengan ijazah yang diperolehnya tak lama kemudian mengajar di sana dan mulai merancang gagasan-gagasan pembaharuan pendidikan. Di al-Azhar, beliaulah orang yang pertama memberikan pelajaran tentang etika, di samping pelajaran tentang politik.

Selain mengajar di al-Azhar ia juga mengajar di Dar ul 'Ulûm dan di rumahnya sendiri. Majelis pelajarannya boleh dikatakan hampir selalu dihadiri banyak mahasiswa. Di Dar ul 'Ulûm, ia memegang mata pelajaran sejarah, dan buku pegangan yang dipakainya adalah Mukaddimah Ibn Khaldun. Sedangkan di rumah ia mengajarkan etika dengan menggunakan buku pegangan Tahdzîb al-Akhlâq karangan filosof Islam kenamaan ibn Maskawaih, dan sejarah Eropa dengan berpegang pada buku karangan F. Guizot dari Perancis.

Di dalam memangku jabatanya ia terus mengadakan perubahan yang sesuai dengan cita-citanya, yaitu memasukkan ide-ide pembaharuan dengan merancang gagasan-gagasan pembaharuan pendidikan. Dengan keyakinannya itu 'Abduh berpendapat bahwa pendidikan dan sains Barat modern adalah kunci kemakmuran dan kejayaan Eropa, dia memandang perlu di galakkan usaha-usaha pengembangan sistem pendidikan baru ke seluruh pelosok Mesir dan negara-negara Islam yang berdekatan agar menjadi negara besar yang kuat. Karena al-Azhar saat itu dipandang sebagai pusat pemikiran dan pendidikan dunia Islam, ia yakin jika al-Azhar berhasil dimodernisasikan, Islam akan menjadi lebih dinamis. Sehingga tak mengherankan jika ia menyerang sistem pengajaran yang tidak sesuai dengan kehidupan modern. ${ }^{13}$

Materi yang diajarkan Muhammad 'Abduh baik di al-Azhar, di rumah, di Dar ul 'Ulûm tidak saja terbatas kepada pengetahuan keagamaan, tetapi juga mencakup logika, filsafat, etika, sejarah, sosial, dan peradaban Eropa. Karena dengan begitu dia bisa mengubah sekaligus memperkaya pemahaman dan pemikiran mahasiswa menuju proses pencerahan secara aktual dan compatible.

${ }^{13}$ Harun Nasution, Muhammad Abduh, h. 13 
Aktifitas Abduh pun kemudian berkembang tidak hanya terbatas dalam mengajar, tetapi dia juga tekun menulis artikel- artikel untuk dipublikasikan di surat kabar, terutama di surat kabar al-Ahrâm. Karena kepiawaiannya dalam menulis, pada tahun 1880 dia dipercaya sebagai pemimpin redaksi al-Waqâi al-Mishriyah, sebuah koran resmi Mesir, yang terbit sejak zaman Muhammad Ali (1765-1849). Surat kabar ini oleh Muhammad 'Abduh dan kawan-kawan-nya dijadikan sebagai media untuk mengkritik sikap pemerintah dan aparatur negara yang melakukan penyelewengan. ${ }^{14}$

Di samping kegiatan mengajar dan karang mengarang, Muhammad Abduh, atas pengaruh gurunya, Jamaluddin Al-Afghani, juga terlibat dalam kegiatan politik praktis. Hal ini terbukti ketika pada tahun 1882 terjadi pemberontakan Urabi Pasya untuk menumpas pemberontakan yang membahayakan kedudukan Inggris di Mesir. Muhammad 'Abduh sungguh pun termasuk dalam golongan nasionalis, tapi pada hakekatnya tidak setuju dengan politik Urabi Pasya dalam menentang penguasa dan menuntut parlemen. Menurut pendapatnya, rakyat Mesir belum matang untuk kehidupan parlemen. Oleh karena itu yang diperlukan Mesir pada waktu itu bukanlah parlemen, tetapi pendidikan yang baik yang dapat mencerdaskan rakyat. Untuk kehidupan perlemen rakyat harus dicerdaskan lebih dahulu. ${ }^{15}$ Menurut pendapatnya pula, bahwa menuntut parlemen dengan menggunakan kekuasaan militer merupakan langkah yang tidak tepat sama sekali. Pemberontakan tidak akan menyelesaikan masalah dan tidak menguntungkan Mesir, bahkan ia justru akan mengundang negara asing menduduki negeri itu.

Walau demikian, setelah ternyata bahwa gerakan telah berubah menjadi perlawanan terhadap kekuasaan Barat, ia akhirnya turut dalam gerakan tersebut yang menyebabkan ia dijatuhi hukuman dibuang keluar negri untuk masa tiga tahun.

Tidak lebih dari satu tahun di Suriah, 'Abduh menyusul gurunya, Jamaluddin al-Afgani ke Perancis. Di sana mereka mendirikan surat kabar al-Urwatul Wutsqa pada tahun 1884, dengan maksud membangkitkan solidaritas muslim dalam menentang ekspansi Eropa ke dunia Islam.

\footnotetext{
${ }^{14}$ Harun Nasution, Muhammad Abduh, h. 13

${ }^{15}$ Harun Nasution, Muhammad Abduh, h. 13
} 
Sayang, umur surat kabar itu tidak berlangsung lama. Karena dibinasakan oleh penguasa-penguasa Inggris. Dengan terhentinya penerbitan surat kabar perjuangan tersebut pada tahun berikutnya, tahun 1885, 'Abduh meninggalkan Paris menuju Bairut-Lebanon dan mengajar di sana sambil menulis beberapa buku antara lain Risâlah al-Tauhîd (dalam bidang Balaghah), Nahj Al-Balâhgah ( komentar menyangkut kumpulan pidato dan ucapa Imam Ali ibn Abi Thalib), Al-Radd 'alâ Al-Zhahriyyin (terjemahan karya Jamaluddin Al-Afghani dalam bahasa Persia yang berisi bantahan terhadap orang yang tidak mempercayai wujud tuhan), dan Syarah Maqâmat Badi' Al-Zamân (buku yang berkaitan dengan bahasa dan sastra Arab.

Lebanon bagi Abduh merupakan persinggahan intelektual strategis untuk menjangkarkan humanisme universal. Untuk itu, dia kemudian mendirikan suatu organisasi yang bertujuan menggalang kerukunan antar umat di samping itu dia bisa memasukkan misi Islam dalam pergaulan masyarakat internasional (international community). Ini terbukti dengan masuknya beberapa artikel pada media Inggris yang sifatnya mengangkat Islam ke permukaan secara objektif, di mana sebelumnya tidak pernah terjadi di media Barat. Tetapi, dia dan organisasi yang dibangunnya itu lagi-lagi di curigai memiliki tujuan politik oleh penguasa Turki di Beirut sehingga penguasa tersebut mengusulkan kepada pemerintah Mesir untuk mencabut hukuman pengasingan 'Abduh agar dia kembali ke Mesir.

Pada tahun 1888, Khedevi Taufik mengizinkan 'Abduh untuk pulang ke Kairo. Karena tidak boleh mengajar, mengingat dia dianggap terlalu berpengaruh terhadap kaum muda, dia dipercaya menjadi hakim di pengadilan daerah Banha dan Zagazig. Kemudian ia dipindahkan ke Cairo menjadi hakim di pengadilan negeri Abidin dan pada akhirnya pada tahun 1890, ia diangkat menjadi penasehat pada Mahkamah Tinggi.

Selama menjalankan tugasnya sebagai hakim ia berusaha membawa perbaikan di Universitas al-Azhar yang semenjak lama telah menjadi idamannya. Ia ingin membawa ilmu-ilmu modern yang sedang berkembang di Eropa ke dalam al-Azhar. Sebagaimana dijelaskan oleh harian Al-Manâzir, ia ingin membuat al-Azhar serupa dengan universitas-universitas yang ada di Barat.

Perbaikan yang diadakannya dalam bidang administrasi adalah 
penentuan honorarium lagi layak bagi ulama al-Azhar, sehingga mereka tidak tergantung lagi pada usaha masing-masing atau pada pemberian dari mahasiswa mereka. Asrama mahasiswa ia perbaiki dengan memasukkan air mengalir ke dalamnya. Beasiswa mahasiswa juga dinaikkan jumlahnya.

Untuk keperluan administrasi, ia dirikan gedung tersendiri dan untuk membantu rektor, ia angkat pegawai-pegawai yang sebelumnya memang tidak ada. Selanjutnya ia perpanjang masa belajar dan perpendek masa libur. Juga dibuat peraturan yang melarang pembacaan hâssyiah (komentar) dan syarh (penjelasan panjang lebar tentang teks pelajaran) kepada mahasiswa untuk empat tahun pertama.

Ia kemudian diangkat menjadi mufti Mesir pada tahun 1899. Dalam kedudukannya sebagai mufti Mesir, ia mempunyai wewenang dalam menafsirkan hukum-hukum syariah untuk seluruh Mesir. Fatwa yang dikeluarkannya bukan hanya untuk keperluan resmi pemerintah, tetapi juga untuk kepentingan umum atau masyarakat. dan pada tahun yang sama ia juga diangkat menjadi anggota dari Majlis Syura, dewan legislatif Mesir. Pada mulanya tidak terdapat kerjasama yang baik antara majlis Syura dengan pihak pemerintah Mesir, namun atas usaha Muhammad Abduh, kedua lembaga kenegaraan itu akhirnya dapat melihat bahwa tujuan mereka sama, yaitu kepentingan rakyat Mesir.

Syekh Muhammad 'Abduh adalah seorang pengagum peradaban Eropa, dari kebiasaannya melakukan perjalanan ke negara-negara Eropa, Muhammad Abduh sesungguhnya dapat dikatakan tergolong mampu untuk melakukan perjalanan jauh. Namun sepanjang sejarah hidupnya, ia belum pernah menunaikan ibadah haji. Hal ini karena ada kekhawatiran kalau ia menjalankan kegiatan politik di tanah suci.

Begitulah, tokoh modernis ini tidak sempat melaksanakan niatnya untuk berhaji. Ia meninggal di Iskandaria tahun 1905 akibat penyakit kanker yang dideritanya. Ia mulai jatuh sakit demam sewaktu melakukan perjalanannya yang terakhir ke Sudan. Jenazahnya dimakamkan di kawasan Qurafat al-Mujawirin.

Muhammad Abduh, adalah seorang pembaru sejati, ia pernah merasakan dididik secara tradisional dan berguru pada beberapa ulama al-Azhar yang sebagian besar bersifat konservatif. Lewat Jamaluddin alAfghani, 'Abduh mengenal dunia Barat secara langsung (kedua tokoh ini pernah tinggal di Eropa selama kurang-lebih lima tahun, perkenalan yang 
sangat mempengaruhi sikapnya sebagai intelektual dan tokoh agama. Jadi, pada satu sisi 'Abduh selau dilihat sebagai seorang tokoh 'alim, mujtahid, dan pada sisi lain, 'Abduh juga dianggap sebagai seorang reformis yang toleran, dan kaya akan gagasan-gagasan baru.

Adapun hijrah dan pengembaraan intelektual Muhammad Abduh adalah sebagai berikut:

\section{Karya-Karya Muhammad 'Abduh}

Pembaharuan dalam sejarah Islam tidak bisa dipisahkan dari sosok 'Abduh, beliau tidak hanya dikenal di Mesir atau Timur Tengah, tetapi juga di negara-negar Islam. Hal ini tidak bisa pisahkan dari penyebaran beberapa pemikiran dalam bentuk buku.

Adapun karya-karya Muhammad 'Abduh antara lain:

1. Al-Wâridah, sebuah karya dalam ilmu kalam atau ilmu tauhid dengan metode dan pendekatan tasauf. Inilah karya pertama Muhammad 'Abduh.

2. Risâlah fî Wablat al-Wujûd. Karya ini memang tidak terbit tetapi ini karya Muhammad 'Abduh yang kedua sebagaimana yang diinformasikannya kepada Rasyid Ridha.

3. Falsafatu al-Ijtimâ'Wa al-Târikh. Buku ini adalah karya Muhammad 'Abduh yang ia karang ketika ia mengajar Mukaddimah Ibn khaldun di madrasah al-Ulum. Buku ini hilang ketika ketika ia diusir bersama gurunya Sayid Jamaluddin oleh pemerintah.

4. Hâsyiyat 'Aqâidi al-Jalâli al-Dawani li al-Aqâidi al-Adudiyah. Sebuah karya Muhammad 'Abduh ini mengandung komentar-komentar dia terhadap pemikiran teologi Asy'ariyah.

5. Syarh Nahji Al-Balâghah. Berisi komentar menyangkut kumpulan pidato dan ucapan Imam Ali ibn Abi Thalib.

6. Syarah Maqâlati badii Al-Zamân Al-Hamzani. Sebuah karya yang berkaitan dengan bahasa dan sastra Arab. Buku ini terbit di Beirut

7. Syarh al-Bashâiri al-Nâshiriah. Ini adalah buku Mantiq dengan pendekatan logika yang tinggi.

8. Nizhâmu al-Tarbiyah bi Mashr. Buku ini berisikan tentang pendidikan dengan metode praktis yang dilaksanakan di Mesir.

9. Risâlah al-Tauhîd, suatu karya di bidang ilmu kalam. Risalah ini 
mampu menyihir akidah kebanyakan manusia Mesir yang semula salafi menuju perkembangannya yang khalafi.

10. Taqrîru al-Mahâkim al-Syar'iyah.

11. Al-Islâm wa al-Nashrâniyati máa al-ilmi wa al-Madâniyah. Sebuah karya yang berusaha menampilkan Islam sebagai agama yang mampu menaiki tangga peradaban modern dan maju. Buku ini kumpulan makalah-makalah dari majalah al-Manar yang diedit dan diterbikan oleh Rasyid Ridha.

12. Tafsîr Surât al-Ashr. Tafsir ini disampaikan dalam beberapa kuliahnya.

13. Tafsîr Juz Amma, yang dikarangnya sebagai pegangan para guru ngaji di Maroko pada tahun $1321 \mathrm{H}$.

\section{Menelisik Pembaruan Sistem Pendidikan Menurut Muhammad 'Abduh}

Sebelum lebih jauh memahami pengertian pembaruan sistem pendidikan Islam menurut Muhammad 'Abduh, terlebih dahulu penting untuk mengetahui latar belakang pembaruan pendidikan di dunia Islam. Pembaruan pendidikan di dunia Islam pertama kali dimulai di Kerajaan Usmani. faktor yang melatar belakangi pembaruan pendidikan di dunia Islam tidak berawal dari kesadaran akan rendahnya kualitas pendidikan yang dampaknya dapat dirasakan pada aspek lainnya. Faktor yang melatar belakangi gerakan pembaruan pendidikan bermula dari kekalahankekalahan Kerajaan Usmani dalam peperangan dengan Eropa.

Kekalahan yang dialami Kerajaan Usmani menyebabkan Sultan Ahmad III (1703-1713) amat prihatin. Kemudian ia mulai mengadakan introspeksi diri dengan meneliti dan menyelidiki keunggulan yang dimiliki Barat. Dari sinilah tumbuh sikap baru dari kerajaan Usmani terhadap Barat. Bahkan, Sultan Ahmad III lalu mengambil tindakan dengan mengirimkan duta-duta ke Eropa untuk mengamati keunggulan Barat. Hasil penelitian menemukan perubahan besar yang dimiliki Eropa, yakni kemajuan teknologi dan ilmu pngetahuan modern sehingga Eropa memiliki pasukan yang tangguh. Oleh karenanya, Kerajaan Sultan Ahmad III memandang perlu mengadakan perubahan di Utsmani. Usaha pembaruan sosial-politik di Turki pada akhirnya tidak dapat mengesampingkan pembaruan pendidikan. Tidak sedikit upaya pembaruan di berbagai bidang tersebut harus melalui pendidikan. Misalnya, untuk membangun angkatan perang yang kuat dan tangguh 
perlu dibentuk Sekolah Teknik Militer yang mengajarkan taktik, strategi dan lain sebagainya. ${ }^{16}$

Upaya pembaruan pendidikan di masa Sultan Ahmad III yang baru berjalan dilanjutkan oleh Sultan II (1807-1839M). Usaha perubahan pendidikan di masa Sultan III yang tidak lancar ditindaklanjuti dengan perubahan pendidikan yang lebih intens. Sebagaimana halnya di dunia Islam, madrasah merupakan satu-satunya lembaga pendidikan umum yang ada dikerajaan Usmani. Di madrasah-madrasah hanya diajarkan pengetahuan agama, pengetahuan umum tidak diajarkan. Sultan Mahmud II sadar bahwa pendidikan madrasah tradisional ini tidak sesuai lagi dengan tuntutan zaman.

Seperti halnya di Turki, pembaruan pendidikan di Mesir yang pelopori oleh Muhammad Ali sangat besar kontribusinya untuk menjadi negara modern. Gerakan pembaruannya telah memperkenalkan ilmu pengetahuan dan teknologi Barat kepada umat Islam, dan sampai suatu waktu dapat menyingkap awan hitam yang menyelimuti pola pikir dan sikap keagamaan sehingga lahirlah intelegensi muslim yang berpengetahuan agama yang luas. $^{17}$

Setelah Muhammad Ali naik tahta menjadi penguasa Mesir, ia mengerahkan usaha untuk memperkuat kekuasaannya. Untuk itu, ia memberikan perhatian tinggi pada bidang militer dan ekonomi. Militer akan memberikan dukungan untuk mempertahankan dan memperbesar kekusaanya. Sedangkan kekuatan ekonomi sangat diperlukan untuk membiayai militer. Untuk memajukan kedua bidang tersebut dibutuhkan ilmuilmu modern. karenanya, Muhammad Ali mencurahkan perhatiannya bagi pendidikan. Untuk hal tersebut, terlebih dahulu ia membentuk kementerian pendidikan.

Pembaruan pendidikan Muhammad 'Abduh tidak terlepas dari pembaruan yang telah dilakukan Muhammad Ali. Sebagaimana diketahui sekolah-sekolah yang dibangun pada masa pemerintahannya berorientasi kepada pendidikan Barat. Ia mendirikan berbagai macam sekolah yang meniru sistem pendidikan Barat dan pengajaran Barat. Di sekolah-sekolah tersebut diajarkan berbagai macam ilmu pengetahuan, sebagaimana yanga

\footnotetext{
${ }^{16}$ Harun Asrohah, Sejarah Pendidikan Islam, (Jakarta: Logos, 1999), h. 130.

${ }^{17}$ Harun Asrohah, Sejarah Pendidikan Islam, h. 30
} 
ada di Barat. Bahkan untuk memenuhi tenaga guru ia mendatangkan tenaga pengajar dari Barat terutama dari Perancis. Disamping itu ia juga mengirim sejumlah pelajar ke Barat yang kelak akan mengembangkan ilmunya di Mesir. $^{18}$

Dari pembaruan dalam bidang pendidikan yang dilakukan Muhammad Ali tersebut kemudian mewariskan dua tipe pendidikan pada abad ke 20; tipe pertama, sekolah-sekolah tradisional dengan al-Azhar sebagai lembaga pendidikan yang tertinggi, tipe kedua, sekolah-sekolah modern baik yang didirikan oleh pemerintah Mesir maupun yang didirikan oleh para missionaris asing. Kedua tipe lembaga pendidikan tersebut tidak mempunyai hubungan sama sekali, masing-masing berdiri sendiri, sekolahsekolah agama berjalan diatas garis tradisional, baik dari segi kurikulum maupun metode pengajaran yang diterapkan, sedangkan sekolah-sekolah modern sepenuhnya berkiblat kepada dunia Barat. ${ }^{19}$

Pada waktu itu, sekolah-sekolah agama semata-mata mengajarkan ilmu agama, dan mengabaikan ilmu-ilmu umum atau tidak mengajarkan ilmu-ilmu yang datang dari Barat. Sementara sekolah-sekolah modern tampil dengan kurikulum yang memberikan ilmu pengetahuan Barat sepenuhnya, tanpa memasukkan ilmu pengetahuan agama ke dalam kurikulumnya.

Di samping itu, sekolah-sekolah yang didirikan oleh bangsa asing atau missionaris tidak hanya dimasuki oleh mereka yang beragama kristen, tapi juga oleh anak-anak muslim, dengan tujuan untuk mendapatkan ilmu pengetahuan yang dapat dipergunakan untuk mencari penghidupan, dengan asumsi bahwa, ilmu-ilmu tersebut lebih penting artinya untuk masa yang akan datang. Namun, kehadiran sekolah tersebut di tengahtengah masyarakat Mesir tampaknya berimplikasi kepada beragamnya masalah sosial yang dihadapi, karena sekolah-sekolah tersebut tidak hanya mentransfer ilmu pengetahuan modern, tetapi juga missi dari agama kristen. Akibatnya, sikap dan tingkah laku yang kemudian ditiru, dicontoh, dan diteladani oleh para siswa yang pada umumnya tumbuh dengan mental yang tidak hanya memuja Barat dan merasa tergantung kepadanya, bahkan lebih dari itu, terdapat diantaranya yang beralih ke agama kristen.

\footnotetext{
${ }^{18}$ Suwito, Sejarah Pemikiran Para Tokoh Pendidikan, (Bandung: Angkasa, 2003), h. 306.

${ }^{19}$ Suwito, Sejarah Pemikiran, h. 306
} 
Selain itu, adanya dua tipe pendidikan tersebut juga berdampak kepada munculnya dua kelas sosial dengan motivasi yag berbeda. Tipe sekolah pertama melahirkan para ulama dan tokoh masyarakat yang enggan menerima perubahan atau perkembangan dan cenderung mempertahankan tradisi. Sedang tipe sekolah kedua melahirkan kelas elit generasi muda yag mendewakan dan menerima perkembangan dari Barat tanpa melakukan filterisasi. Muhammad 'Abduh melihat terdapat segisegi negatif dari kedua bentuk pemikiran itu, sehingga dia mengkritik kedua corak lembaga ini. Oleh karena itu ia memandang bahwa jika pola fikir yang pertama tetap dipertahankan, maka akan mengakibatkan umat Islam tertinggal jauh dan semakin terdesak oleh arus kehidupan dan pola hidup modern. Sementara pola fikir yang kedua Muhammad 'Abduh melihat bahwa pemikiran modern yang mereka serap dari Barat tanpa nilai- nilai religius, merupakan bahaya yang akan mengancam sendi-sendi agama dan moral. ${ }^{20}$

Dari sinilah Muhammad 'Abduh melihat perlunya mengadakan perbaikan terhadap kedua institusi itu sehingga dua pola pendidikan tersebut dapat saling menopang demi untuk mencapai suatu kemajuan, serta upaya untuk mempersempit jurang pemisah antara dua lembaga pendidikan yang kelak akan melahirkan para generasi penerus.

Salah satu proyek terbesar Muhammad 'Abduh dalam gerakannya sebagai seorang tokoh pembaru dalam bidang pendidikan, munculnya dualisme pendidikan sebagai akibat dengan adanya dua institusi yang berbeda, menjadi motivasi bagi Muhammad 'Abduh untuk berusaha keras menghilangkan atau setidaknya meminimalisir dua pola fikir yang ditimbulkan institusi tersebut. ${ }^{21}$

Langkah praktis yang ditempuhnya untuk meminimalisir kesenjangan dualisme pendidikan tersebut adalah dengan equalisasi (upaya menselaraskan, menyeimbangkan) antara porsi pelajaran agama dengan pelajaran umum. Secara operasional, hal itu dilakukan dengan memasukkan ilmu-ilmu umum ke dalam kurikulum sekolah agama, dan memasukkan pendidikan agama ke dalam kurikulum sekolah modern yang didirikan pemerintah sebagai sarana untuk mendidik tenaga-tenaga

\footnotetext{
${ }^{20}$ Suwito, Sejarah Pemikiran, h. 306.

${ }^{21}$ Suwito, Sejarah Pemikiran, h. 306.
} 
adminisrtasi, militer, kesehatan, perindustrian, dan lain sebagainya. Atas usaha Muhammad 'Abduh tersebut maka didirikan suatu lembaga yakni” Majlis Pendidikan Tinggi”.

\section{Ruang Lingkup Pembaharuan Sistem Pendidikan Muhammad 'Abduh}

Menurut Muhammad 'Abduh maka sistem pendidikan Islam harus lebih diberdayakan agar kualitas dan efektifitasnya dapat ditingkatkan, sehingga pendidikan Islam dapat berkompetensi dengan pendidikan modern. Adapun langkah-langkah tersebut adalah:

\section{a. Rekonstruksi Tujuan Pendidikan Islam}

Untuk memahami tujuan pendidikan menurut Muhammad 'Abduh maka penulis akan memaparkan sekilas pemikiran Muhammad 'Abduh tentang manusia. Manusia menurut Muhammad 'Abduh adalah makhluk yang paling serasi dan memiliki kepribadian yang paling sempurna. Manusia sempurna bukan hanya dari segi fisik yang terdiri dari pancaindra dan seluruh anggota tubuhnya, tetapi lebih dari itu manusia adalah makhluk yang sempurna yang dapat berfikir untuk berkreasi dan dengan kreasinya ia bisa menjadi makhluk yang taat kepada Allah. ${ }^{22}$

Untuk meningkatkan pemberdayaan sistem pendidikan Islam, Muhammad 'Abduh menetapkan tujuan pendidikan Islam yang dirumuskannya sendiri. yakni; tujuan hakiki dari pendidikan adalah pendidikan akal dan jiwa dan menyampaikannya pada batas yang memungkinkan anak didik menemukan kebahagiaan yang sempurna. ${ }^{23}$

Pendidikan akal menurut Muhammad 'Abduh adalah sebagai alat untuk menanamkan kebiasaan berfikir yang dapat membedakan antara yang baik dan yang buruk, antara yang membawa manfaat dan yang mendatangkan mudharat. Pendidikan akal adalah tujuan pendidikan yang terpenting. Muhammad 'Abduh berpendapat bahwa pendidikan akal dapat membuat seseorang terhindar dari kebodohan dan menghindarkannya dari penghambaan terhadap tuhan-tuhan yang tidak berhak disembah, sehingga h. 45 .

${ }^{22}$ Muhammad Abduh, Tafsir Juz Amma,terj. Muhammad Baqir, (Bandung: Mizan, 1999),

${ }^{23}$ Muhammad Imarah, al-Amal alKamilah li al-Syaikh Muhammad Abduh, Jilid. III, (Beirut: Dar al-Syuruq, 1993), h. 29. 
ia dapat membedakan mana yang baik dan mana yang buruk, mana yang bermanfaat dan mana yang berbahaya. ${ }^{24}$

Sedangkan pendidikan jiwa adalah menanamkan kemampuan dan sifat-sifat dalam jiwa anak didik, bahkan memenuhinya dengan sifat-sifat yang utama, menjauhkan diri dari sifat-sifat jelek dan mengikuti normanorma sosial. ${ }^{25}$ Dengan menanamkan kebiasaan berfikir, Muhammad 'Abduh berharap kebekuan intelektual yang melanda kaum muslimin saat itu dapat dicairkan, dan dengan pendidikan spritual, diharapkan akan dapat melahirkan generasi baru yang tidak hanya mampu berfikir kritis, tetapi juga memiliki akhlak mulia serta jiwa yang bersih, sehingga sikapsikap yang mencerminkan kerendahan moral dapat dihilangkan.

Pendidikan menurutnya tidak boleh lepas dari nilai akal dan jiwa, jika salah satunya hilang, maka hilang jugalah tujuan dari pendidikan tersebut. Jika nilai-nilai pendidikan akal dan jiwa bersatu dalam jiwa seseorang maka ia mendapatkan suatu manfaat dan akan terhindar dari bahaya.

Menurutnya meskipun seseorang pintar atau menguasai ilmu pengetahuan agama, tetapi tidak memiliki akhlak yang mulia, maka hal itu tidak memberikan nilai manfaat yang banyak.Memang orang yang berilmu itu tidak semua berakhlak mulia dan saat itulah pendidikannya tidak berhasil kecuali dengan sedikit manfaat.

Rumusan tujuan pendidikan Muhammad Abduh yang demikian itu tidak bisa dilepaskan dari pengaruh kehidupan masyarakat pada masa itu. Kondisi umat Islam yang mengagungkan sikap taklid, bid'ah dan khurafat yang sesungguhnya menafikan nilai-nilai akal dan jiwa.

Muhammad Imarah mengungkapkan bahwa tujuan pendidikan menurut Muhammad Abduh adalah:

1. Terciptanya harmoni antara ilmu-ilmu keislaman yang merupakan basis keimanan setiap muslim

2. Kedamaian hidup akhirat

3. Sarana kebahagiaan dunia

4. Pendidikan akal dan jiwa

5. Pembinaan akhlak.

\footnotetext{
${ }^{24}$ Muhammad Imarah, al-Amal alKamilah, h. 29.

${ }^{25}$ Muhammad Imarah, al-Amal alKamilah, h. 29.
} 
Dalam usahanya memperbaiki kurikulum pendidikan di al-Azhar, Muhammad 'Abduh menekankan pentingnya pendidikan akhlak yang menurutnya telah hilang dan memasukkan beberapa buku pedoman etika yang diajarkan oleh guru, bahkan ia menjadikannya sebagai salah satu syarat kelulusan. Selain diajarkan ilmu agama dan umum, muridnya diajarkan dan dibiasakan keterampilan sehingga pendidikan tidak hanya untuk mencetak pegawai negeri.

Dari rumusan tujuan pendidikan tersebut, dapat dipahami bahwa yang ingin dicapai oleh Muhammad 'Abduh adalah tujuan yang mencakup aspek akal dan aspek spiritual. Ia menginginkan terbentuknya pribadi yang memiliki struktur jiwa yang seimbang antara aspek akal dan spiritual.

Nampaknya Muhammad 'Abduh berkeyakinan bahwa bila kedua aspek tersebut dididik dan dikembangkan, dalam arti akal dicerdaskan dan jiwa dididik dengan akhlak agama, maka umat Islam akan dapat berpacu serta dapat mengimbangi bangsa-bangsa yang telah maju kebudayaannya.

\section{b. Menggagas Kurikulum yang Integral}

Sistem pendidikan yang diperjuangkan Muhammad 'Abduh adalah sistem pendidikan fungsional yang bukan impor, yang mencakup pendidikan universal bagi semua anak, laki-laki maupun perempuan. Kurikulum yang yang ideal menurut Muhammad Abduh adalah:

\section{1) Tingkat Sekolah Dasar}

Institusi sekolah dasar setiap anggota masyarakat wajib memiliki kemampuan dasar seperti membaca, menulis, dan berhitung. Di samping itu mereka semua berhak mendapatkan pendidikan agama. Adapun isi dan lama pendidikan haruslah beragam, sesuai dengan tujuan dan profesi yang dikehendaki oleh pelajar, dan semua kalangan berhak untuk mendapatkan pendidikan, seperti anak petani, pedagang dan lain sebagainya. ${ }^{26}$

Di tingkat ini hendaknya diajarkan dan ditanamkan sifat-sifat mulia, seperti keutamaan kejujuran dan amanah. Menurutnya, kejujuran dan

${ }^{26}$ Muhammad Imarah, al-Amal alKamilah, h.. 80. 
amanah adalah jembatan untuk menuju kebahagiaan. Begitu juga ditingkat ini sebaiknya diajarkan bahasa asing sebagai persiapan bagi siapa yang akan bekerja atau mengabdi. Meskipun pendidikan sekolah dasar tidak berorientasi pada pencetakan anak didik untuk bekerja tetapi institusi ini harus membantu mengantarkan anak didik untuk bekerja.

Tujuan yang ingin dicapai pada tingkatan ini adalah agar anak didik dapat hidup secara mandiri, dapat mengendalikan hidup mereka dan bisa bergaul dengan sesama manusia.

Menurut Muhammad Imarah secara rinci pemikiran Muhammad 'Abduh tentang kurikulum dalam pengertian mata pelajaran yang diajarkan di sekolah formal tingkat dasar sebagai berikut: ${ }^{27}$

a. Akidah. Adapun buku agama yang dipelajari pada sekolah dasar adalah buku ringkasan akidah Islam ahli sunnah dengan tidak mengajarkan perbedaan pendapat disertai dengan dalil-dalil yang mudah diterima oleh akal. Pelajaran agama Islam harus menunjukan ayat-ayat alQuran dan hadist shahih. Pada periode ini tidak boleh mengajarkan perbandingan agama seperti perbandingan agama Islam dengan Kristen.

b. Fiqh dan akhlak. Buku agama yang dipelajari di sekolah dasar juga berhubungan dengan halal dan haram dari perbuatan sehari-hari, tentang akhlak baik dan buruk serta bahaya bid'ah. Semua itu dijelaskan dengan menyertakan ayat-ayat al-Quran, hadist shahih, dan memberikan contoh-contoh kisah tentang orang jujur dari umat terdahulu. Doktrin yang harus dilakukan oleh guru pada tingkatan ini adalah segala perbuatan yang tidak bersandar dari Allah dan rasul Saw tidak boleh diterima.

c. Sejarah. Ringkasan sejarah yang mencakup sejarah nabi Muhammad Saw dan sahabatnya yang berhubungan dengan akhlak mulia, perbuatan mulia, pesan-pesan agama yang berhubungan dengan pengorbanan jiwa dan harta. Selain itu juga boleh ditambah dengan sejarah khilafah Utsmaniyah. Semua itu hendaknya diajarkan dengan ringkas dan mudah diterima akal.

${ }^{27}$ Muhammad Imarah, al-A'mal alKamilah, h.. 80. 


\section{2) Tingkat Sekolah Menengah}

Pada masa Muhammad Abduh sekolah menengah dikelola oleh negara. Sekolah ini dipersiapkan untuk menjadi pegawai negeri di berbagai sektor pemerintahan.Bagi siswa tingkat menengah, hendaknya diberikan mata pelajaran syari'ah, kemiliteran, kedokteran, serta pelajaran tentang ilmu pemerintahan bagi siswa yang berminat terjun dan bekerja di pemerintahan. Kurikulumnya harus meliputi buku yang memberikan pengantar pengetahuan, seni logika, prinsip penalaran, dan tata cara berdebat. Teks tentang doktrin, yang menyampaikan soal-soal seperti dalil rasional, menentukan posisi tengah dalam upaya menghindarkan konflik, pembahasan lebih rinci mengenai perbedaan antara Islam dan Kristen, serta keefektifan doktrin Islam dalam membentuk kehidupan di dunia dan akhirat.

Kurikulum yang diajarkan pada sekolah menengah, adalah semua yang ada disekolah dasar, hanya saja materi-materi lebih diperdalam. Karena sekolah menengah diorientasikan untuk bekerja di pemerintahan, maka tujuan yang hendak dicapai pada tingkat ini adalah menciptakan anak didik dapat menjaga amanah dalam melaksanakan tugas-tugas di pemerintahan kelak.

Muhammad Imarah berpendapat bahwa kurikulum sekolah menengah menurut Muhammad 'Abduh mencakup seluruh kurikulum sekolah dasar dan pengembangannya. Adapun kurikulum yang baru pada tingkatan ini ialah sebagai berikut: ${ }^{28}$

a. Pengantar ilmu, termasuk didalamnya ilmu mantik dan dasar-dasar penelitian dan aturan berdiskusi

b. Akidah yang mencakup usul fiqh dan sebagian kecil tentang perbedaan pendapat dalam madzhab Islam yang lebih dikenal firqah Islam. Selain itu materi aqidah ini juga manfaat aqidah Islam dalam kehidupan yang maju untuk mencapai kebahagiaan ukhrawi?

c. Tentang hukum halal dan haram dan aklaq disini dijelaskan manfaat dan bahaya dari hukum halal dan haram yang lebih luas dari kurukkulum disekolah dasar. Sehingga anak didik dapat mengetahui bahwa akhlaq yang mulia dapat membuat hati tenang. Semua materi hukum dan akhlaq pada tingkat ini juga harus didukung oleh yat-ayat al-Quran dan hadist hadits yang shahih.

${ }^{28}$ Muhammad Imarah, al-Amal alKamilah, h. 83. 
d. Sejarah agama yang terdiri dari uraian rinci tentang sirah al-nabawiyah dan sahabatnya, futuhat al-Islamiyah, khilafat Usmaniyah. Jika menguraikan sejarah dari aspek politik maka hendaknya tidak keluar dari tujuan agama. Dalam tingkatan ini juga diterangkan sejarah pemerintahan atau khilafat Islam di seluruh dunia. Pengajaran sejarah pada tingkatan ini untuk membangkitkan semangat Islam dalam mencontoh yang baik dalam sejarah itu, sehingga Islam dalam lebih maju lagi.

\section{3) Tingkat Perguruan Tinggi}

Menurut Muhammad Abduh untuk pendidikan tinggi, yaitu untuk orientasi guru dan kepala sekolah, maka sepatutnya menggunakan kurikulum yang lebih lengkap yang mencakup antara lain tafsir al-Quran, ilmu bahasa, ilmu hadits, studi moralitas, prinsip-prinsip figh, histografi, seni berbicara dan meyakinkan, teologi, serta pemahaman doktrin secara rasional. Pelajaran agama pada tingkat ini (calon pendidik) yang kemudian disebut oleh Muhammad 'Abduh al-Urafah al-Ummah. ${ }^{29}$

Muhammad Imarah berpendapat bahwa kurikulum perguruan tinggi menurut Muhammad Abduh mencakup:

a. Tafsir al-quran. Yang paling penting dalam pelajaran ini adalah membaca dan memahami al-quran yang diturunkan oleh Allah dengan sejumlah hikmahnyaBahasa Arab dan tata bahasanya

b. Bahasa Arab dan tata bahasanya.

c. Hadits, khususnya yang dikutip para mufassir dalam menafsirkan alQuran

d. Akhlak dengan penjelasan yang rinci

e. Ushul fiqh

f. Sejarah

g. Logika dan khitabah

h. Ilmu kalam dan penelitian agama

Kalau dilihat dari kurikulum yang dikemukakan Muhammad 'Abduh pada tiga tingkatan diatas, secara umum menggambarkan kurikulum

${ }^{29}$ Muhammad Imarah, al-A'mal alKamilah, h. 83. 
agama. Adapun ilmu-ilmu Barat tidak dimasukkan Muhammad 'Abduh ke dalam kurikulum, karena menurutnya ilmu-ilmu umum itu dipelajari bersamaan dengan ilmu-ilmu yang diuraikan di atas. Dengan kata lain, ilmu-ilmu umum hendaknya terintegrasi ke dalam ilmu-ilmu agama. Selanjutnya Muhammad 'Abduh tidak merinci karena menurutnya setiap sekolah memiliki kecenderungan-kecenderungan atau penekananpenekanan yang berbeda-beda antara satu dengan yang lainnya.

Tingkatan yang terakhir ini harus dibimbing atau diajar oleh guru-guru ahli dan berakhlak mulia. Mahasiswa yang kuliah juga tidak diberikan ijazah kecuali setelah mereka mengikuti ujian yang mendalam dan komprehensif.

Dari beberapa kurikulum yang dicetuskan Muhammad 'Abduh, kelihatannya ia menghendaki bahwa dengan kurikulum yang demikian diharapkan akan melahirkan beberapa kelompok masyarakat, seperti kelompok masyarakat awam yang meliputi petani, pedagang, pekerja industri dan lain sebagainya. Demikian juga diharapkan lahirnya kelompok masyarakat golongan pejabat, pemerintahan dan militer, serta kelompok masyarakat golongan intelek dan pendidik. Semua itu tentunya harus memiliki wawasan dan pengetahuan tentang agama sebagai suatu alat kontrol yang dapat menunjang.

Dengan kurikulum yang demikian Muhammad 'Abduh mencoba menghilangkan jarak dualisme dalam pendidikan yang ada pada saat itu dan merencanakan suatu kurikulum pendidikan Islam yang integral ( integrated curriculum)

\section{c. Penerapan Metode yang Variatif}

Sebagaimana para ahli pendidikan Islam lainnya menggunakan berbagai macam metode pendidikan, begitu juga halnya dengan Muhammad 'Abduh. Ketika belajar di al-Azhar Muhammad 'Abduh merasa sangat kecewa terhadap metode pengajaran yang dipakai oleh para syekh. Ia memandang metode pengajarannya membuat siswa jenih, beku dan dogmatis. Beliau juga mengkritik cara kajian buku-buku yang lebih banyak terfokus pada tafsiran-tafsiran orang daripada teks aslinya. Untuk mengatasi masalah tersebut Muhammad Abduh melihat akan pentingnya pembaruan dalam metode pendidikan.

Di antara metode yang digunakan Muhammad 'Abduh adalah: 


\section{1) Metode Menghapal}

Dalam bidang metode pengajaran Muhammad Abduh membawa cara baru dalam dunia pendidikan saat itu. Metode pengajaran yang dipraktekkan di sekolah-sekolah saat itu memakai metode menghapal tanpa disertai pemahaman. Karena metode menghafal ini Muhammad 'Abduh mengkritik, prustasi dan membenci belajar saat ia belajar di mesjid Ahmad Thanta. Muhammad 'Abduh mengkritik metode menghafal saat itu tidak berarti membenci metode tersebut, namun ia tidak setuju dengan metode ini bila tidak disertai dengan pemahaman dan penalaran.

Menghapal dalam proses belajar tidak mungkin dapat dinafikan karena hal tersebut sangat esensial. Terbukti ummat Islam banyak yang hafal alQuran, termasuk Muhammad 'Abduh. Dengan demikian dapat dipastikan bahwa Muhammad 'Abduh tidak melarang metode menghafal tetapi dapat diketahui dari pengalaman dan kritikannya terhadap metode menghafal, sepertinya ia berpendapat bahwa metode menghafal seharusnya disertai dengan pemahaman. Artinya, selain memang perlu menghafal juga yang terpenting siswa harus mengerti apa yang dipelajarinya.

\section{2) Metode Diskusi}

Dari pengalaman belajar Muhammad 'Abduh dan kritikannya terhadap meode menghapal, dapat diketahui bahwa ia mementingkan pemahaman, hal itu didukung oleh fakta metode yang ia praktekkan dan ia sukai adalah metode diskusi.

Muhammad 'Abduh berpendapat bahwa metode pendidikan dan pengajaran hendaknya memperhatikan kemampuan dan keinginan anak didik. Dalam kata lain, metode pengajaran yang memberikan kebebasan berfikir dan berbuat bagi anak didik. Menurutnya metode yang banyak memberi kebebasan berfikir dan berkreasi dalam pendidikan dan pengajaran adalah metode diskusi. Metode diskusi inilah yang banyak dipraktekkan oleh Muhammad 'Abduh dalam mengajar di Universitas al-Azhar.

Muhammad Abduh menghidupkan metode diskusi dalam memahami pengetahuan yang sebelumnya banyak mengarah kepada taklid semata terhadap pendapat ulama-ulama tertentu yang dianggap mempunyai pengaruh. Hal tersebut diubahnya dengan jalan pengembangan kebebasan intelektual di kalangan mahasiswa al-Azhar. Demikian juga halnya dengan sikap ilmiah, terutama dalam memahami sumber-sumber ilmu agama yang 
selama ini seolah-olah sudah memiliki landasan yang tidak dapat di ganggu gugat oleh pemikiran dan kemajuan zaman.

Usaha Muhammad 'Abduh ini tidak mudah ia realisasikan, terutama karena mendapat tantangan dari kalangan ulama-ulama al-Azhar ketika itu yang masih memiliki pola fikir tradisional yang belum bisa menerima pembaruan, terutama ilmu-ilmu yang datangnya dari Barat yang mereka anggap sebagai sesuatu yang bertentangan dengan konsep dan ajaran Islam. ${ }^{30}$

Meskipun mendapat tantangan, atas usul beliau maka pada tanggal 15 Januari 1895 dibentuk dewan pimpinan al-Azhar yang terdiri dari ulamaulama besar dari empat mazhab. Muhammad 'Abduh diangkat menjadi anggota dewan sebagai wakil dari pemerintah Mesir, beliaulah yang menjadi penggerak dari dewan ini untuk melakukan berbagai perbaikan-perbaikan di al-Azhar.

\section{3) Metode Teladan}

Guru sebagai pendidik seharusnya mendidik anak didik untuk memiliki sifat cinta kasih terhadap sesama manusia. Dalam mengajarkan pesan cinta kasih itu guru dapat memberi teladan kepada anak didik. Teladan yang baik jauh lebih berpengaruh kepada jiwa mereka (anak didik)dari pada sekedar teori. ${ }^{31}$ Selain aspek teladan guru juga harus memperhatikan dan memilih gaya bahasa yang serasi untuk meyampaikan pesan sifat cinta kasih itu. Gaya bahasa yang digunakan guru juga harus memperhatikan aspek efektifitas dan efesiensi

Dari uraian tersebut diatas dapat ditarik kesimpulan bahwa pengajaran yang bertujuan untuk membina akhlak, hendaknya guru memakai bahasa yang mudah dipahami, jelas dan tegas dan disampaikan dengan uslub atau cara yang baik

\section{4) Metode Latihan}

Untuk mengintegrasikan antara pendidikan akal dan jiwa, guru di sekolah menggunakan metode latihan seperti melatih anak didik untuk

\footnotetext{
${ }^{30}$ Abdul al-Gaffar, Imam Muhammad Abduh, (Kairo: Dar al-Anshar, 1980), h. 65.

${ }^{31}$ Rasyid Ridha, Tafsir al-Manar. Jilid 11, h. 581-586.
} 
shalat. Bagi sekolah yang memiliki anak didik beragama non Islam seperti Kristen, maka guru hendaknya tidak menyuruh mereka untuk melaksanakan shalat, namun meskipun mereka (anak didik) yang non Islam tidak melaksanakan Shalat, tetapi nilai-nilai spritual tersebut tidak boleh hilang dari mereka. ${ }^{32}$

Ada hal yang harus diperhatikan dalam memahami pemikiran Muhammad 'Abduh tentang metode pendidikan dan pengajaran. Ia berpendapat bahwa metode penyampaian ilmu kepada manusia tidak selalu sama. Metode dapat berubah sesuai dengan perubahan tempat dan waktu. Contoh yang dikemukakan Muhammad 'Abduh adalah teknologi pos dalam pengiriman uang. Mestinya amanah penitipan uang mesti disampaikan langsung kepada orang yang bersangkutan, tetapi dengan adanya teknologi pos ini maka caranyapun mengalami perubahan. ${ }^{33}$

\section{d. Kompetensi Pendidik}

Sebagai pemegang amanat orang tua dan pelaksana pendidikan Islam, guru tidak hanya bertugas menyampaikan pelajaran ilmiah kepada peserta didik. Tugas guru hendaknya merupakan kelanjutan dan sinkron dengan tugas orang tua, yaitu memberi pendidikan yang berwawasan manusia seutuhnya.

Tidak sembarang orang dapat melaksanakan tugas guru. Tugas ini menuntut banyak persyaratan, baik segi profesional, biologis, psikologis, maupun paedagogis-didaktis. Para pemerhati pendidikanpun dari masa kemasa berusaha membahas masalah ini, termasuk diantaranya Muhammad 'Abduh.

Menurut Muhammad 'Abduh di Mesir pada dasarnya subtansi pendidikan telah hilang karena para pendidik sudah tidak memiliki kepedulian kepada para murid yang diajarinya. Guru sepertinya tidak mementingkan untuk memberikan pemahaman kepada siswa, dan yang terpenting adalah tugas mereka sudah selesai, karena itu sulit untuk mencapai tujuan. Suatu kritikan Muhammad 'Abduh terhadap guru-guru Mesir pada masanya. Mereka tidak perduli dengan keadaan muridnya, hubungan antara guru dengan murid terbatas hanya dikelas, hal ini semakin semakin diperparah dengan moral yang guru kurang mulia.

\footnotetext{
${ }^{32}$ Muhammad 'Imarah, Op. Cit., h. 31.

${ }^{33}$ Tafsir al-Manar, Jilid V, h. 171.
} 
Bahkan lebih ekstrimnya lagi tidak ada interaksi antara guru dengan murid.

Pendidikan menurut Muhammad 'Abduh hendaknya berusaha menghasilkan manusia yang berakhlak mulia.Oleh karena itu pendidikan harus menghasilkan insan-insan berakhlak mulia. Karena diantara hasil yang akan dicapai dalam pendidikan adalah pembinaan akhlak mulia, maka untuk mencapai tujuan ini sudah pasti guru sebagai tenaga pendidik harus berakhlak mulia.

Muhammad 'Abduh berpendapat bahwa guru yang profesional harus memiliki kompetensi,berprilaku yang baik, berpengetahuan luas dan menguasai materi. Menurut Muhammad Imarah, Muhammad 'Abduh menganut mazhab pendidikan demokratis. Ia berpendapat pendidikan harus memperhatikan perkembangan dan periode anak, sehingga bisa menyesuaikan tujuan, kurikulum dan metode pengajaran yang layak digunakan oleh guru.

Selanjutnya Muhammad 'Abduh berpendapat bahwa seorang guru harus memiliki pengetahuan tentang akhlak dan sekaligus memiliki akhlak yang baik. Selain itu juga guru harus memiliki akidah yang baik dan pemikiran yang benar. Lebih lanjut ia berpendapat bahwa guru harus senantiasa menjaga iffah, berani, dan energik, sehinga ia dapat melaksanakan semua tugasnya sebagai guru dengan baik.

Sebagai panduan operasional dalam pelajaran agama, hendaknya guru menerapkan nilai-nilai berikut: ${ }^{34}$ (1)Menghindari buruk sangka terhadap agama lain. Guru berusaha mempersatukan semua agama tetapi bukan mempersatukan aqidahnya (2)Membangkitkan rasa kemanusiaan. Hendaknya ditanamkan oleh guru kepada semua anak didik bahwa semua manusia bersaudara bersumber dari satu bapak dan satu ibu. Maka hendaknya yang satu memberi manfaat bagi yang lainya. Oleh sebab itu semua manusia harus saling mencintai.

\section{e. Pemberian Motivasi terhadap Anak Didik}

Untuk membahas point ini lebih dahulu penting untuk mengetahui bagaimana pendapat Muhammad 'Abduh tentang fithrah dalam kaitannya dengan perkembangan anak didik.

\footnotetext{
${ }^{34}$ Muhammad Imarah, al-Amal alKamilah, h. 57.
} 
Menurut Muhammad 'Abduh, pada umumnya pendidikan sekolah pada masa kerajaan Utsmani kurang membuahkan hasil, dan para lulusan sekolah-sekolah dasar itu tidak memperhatikan terjadinya proses perkembangan fitrah mereka. Terbukti bahwa perilaku mereka tidak lagi mencerminkan kesucian fitrah mereka.

Kritikan Muhammad 'Abduh di atas tentang pelaksanaan pendidikan kerajaan Utsmani tersebut lebih lanjut dapat dipahami dari pendapatnya bahwa setiap individu memiliki potensi fitrah yang baik, namun individu tersebut kemudian dapat berubah-ubah corak dan bentuknya sejalan dengan pendidikan yang ditempuh atau dijalaninya. Lebih tegas ia mengatakan bahwa manusia tidak lagi apa-apa kecuali dengan pendidikan dengan memahami ajaran yang dibawa oleh rasul, baik dari aspek hukum, hikmah dan lain lain. ${ }^{35}$

Dari uraian tentang uraian fitrah manusia tersebut diatas, dapat dipahami bahwa menurut Muhammad 'Abduh, manusia dalam hal ini anak didik dilahirkan dengan memiliki potensi-potensi. Dengan kata lain manusia lahir ke dunia ini tidak seperti kertas kosong sebagaimana dalam teori tabula rasa. Di antara potensi-potensi lahiriyah (bawaan) manusia, khususnya potensi aqliyahnya tidak berkembang begitu saja tanpa ada proses pendidikan. Artinya, potensi 'aqliyah itu tidak berfungsi sempurna tanpa adanya proses pendidikan. Oleh sebab itu pendidikan adalah sarana untuk mengembangkan potensi 'aqliyah manusia itu. Pada tahap ini Muhammad 'Abduh lebih dekat pada aliran konvergensi daripada aliran nativisme dan empirisme.

Lebih lanjut dalam membicarakan fitrah manusia Muhammad 'Abduh pernah mengutip hadist nabi pada pidato resepsi di al-jami,ah alkhairiyah; kullu maulûdin yûladu 'alâ al-fitrah fa abâwahu yuhawwidânihi au yunasshirânihi au yumajjisânihi. Kata "yûladu 'alâ al-fitrah" adalah menunjukkan pada potensi bawaan manusia, sedangkan tiga fi'il mudhâri itu (yuhawwidânihi, yunasshirânihi, dan yumajjisânihi) mengidentifikasikan suatu proses perkembangan anak didik melalui pendidikan.

Adapun tugas dan kewajiban anak didik sangat bermacam macam. Dan diantara tugas anak didik terhadap pendidikan menurut Muhammad 'Abduh adalah dengan belajar sungguh-sunguh. Pendapatnya ini didukung

${ }^{35}$ Muhammad Imarah, al-Amal alKamilah, h. 57. 
oleh data bahwa ketika ia mengajar di Universitas Al-azhar, ia mewajibkan mahasiswa untuk bersungguh-sunguh dalam belajar, tidak boleh memiliki kesibukan selainnya. Ia juga mewajibkan mahasiswa untuk mengikuti ujian umum tahunan setelah mereka mengikuti ujian sesuai dengan tingkatan, kepintaran, dan kapasitas keilmuan mereka secara lisan. Dari uraian tersebut diatas tentang kewajiban belajar dan ujian, dapat dipahami bahwa Muhammad 'Abduh menerapkan disiplin belajar yang baik.Kemudian sistem ujian umum tahunan yang dimaksud berbentuk tes tulis setelah dilakukan tes lisan untuk melihat kemampuan mahasiswa yang variatif. Dengan demikian di antara tugas anak didik terhadap pendidikan adalah bersungguh-sungguh belajar.

Pada fithrahnya manusia ingin mulia dan dimuliakan. Salah satu bentuk penghargaan di sekolah terhadap anak didik adalah dengan pemberian beasiswa, baik beasiswa prestasi maupun beasiswa tidak mampu. Dalam hal ini Muhammad 'Abduh memberikan beasiswa bagi para mahasiswa berprestasi sebagai motivasi untuk lebih bersemangat lagi dalam belajar.

Sistem pendidikan yang memberikan beasiswa adalah salah satu bentuk memotivasi anak didik yang masih relevan sampai sekarang. Beasiswa sangat berguna untuk membangkitkan semangat belajar yang berimplikasi pada kompetisi anak didik.

\section{Penutup}

Berdasarkan data yang diuraikan di atas, dapat ditarik kesimpulan bahwa corak pemikiran pendidikan Muhammad Abduh cenderung pada aliran progresif. Hal ini terlihat pada pemikirannya tentang tujuan pendidikan, yaitu tujuan universal, tujuan institusional dan tujuan korikuler.

Dalam tujuan institusional pada sekolah dasar misalnya, ia berpendapat bahwa tujuan institusionalnya agar anak didik dapat hidup dengan benar, dapat mengatur diri sendiri, dan dapat bergaul dengan sesama manusia.Dalam bidang kurikulum ia telah merinci ilmu-ilmu yang wajib 'ain. Ilmu yang wajib 'ain ini bukan saja ilmu-ilmu agama, tetapi juga mencakup ilmu-ilmu umum. Rumusan ilmu-ilmu yang wajib 'ain juga memiliki sifat fleksibel dan terbuka akan perubahan karena pada saat itu, ulama masih banyak yang kaku mengapresiasi ilmu-ilmu umum, 
dengan kata lain masih terdapat ulama yang berusaha mambuat dikotomi dalam ilmu.

Dalam bidang metode pendidikan Muhammad Abduh sangat akomodatif dalam multi metode pengajaran dan sangat mengecam metode yang hanya mementingkan hafalan tanpa pemahaman. Pemikiran Muhammad Abduh ini tentu cukup progresif karena metode pengajaran pada masa itu masih didominasi oleh hapalan.

Dalam bidang pendidik pemikiran progressive dapat dilihat dari kritikannya tentang hubungan antara guru dan murid yang terbatas hanya dikelas saja. Kemudian kriteria kompetensi guru pada saat itu belum dikemukakan, ia sudah mengemukakan bahwa seorang guru harus memiliki kompetensi.

Dalam bidang anak didik pemikiran progressive Muhammad Abduh dapat dilihat dari pemikiranya tentang faktor yang mempengaruhi perkembangan anak bersifat nativis, empiris, dan konvergen.Perkembangan anak dari umur kandungan sampai dua tahun dipengaruhi oleh faktor nativis, setelah dua tahun sampai seseorang meninggal dunia dipengaruhi oleh faktor empiris.Adapun kedudukan faktor konvergen menurut Muhammad Abduh adalah integrasi faktor nativis dan faktor empiris dalam perkembangan anak dua faktor yang saling mempengaruhi.

\section{Pustaka Acuan}

Abu Dawud, Sunan Abi Dâwûd, Beirut: Dâr al-Kutub al-'ilmiyyah,1996

Harun Nasution, Pembaharuan dalam Islam, Jakarta: Bulan Bintang, 1975 , Muhammad Abduh dan Teologi Rasional Mu'tazilah, Jakarta: Universitas Indonesia,

Harun Asrohah, Sejarah Pendidikan Islam, Jakarta: Logos, 1999

Muhammad Abduh, Tafsir Juz Amma,terj. Muhammad Baqir, Bandung: Mizan, 1999

Muhammad Imarah, al-Amal al-Kamilah li al-Syaikh Muhammad Abduh, Jilid. III, Beirut: Dar al-Syuruq, 1993

Maryam Jameelah, Islam dan Modernisasi, Surabaya: Usaha Nasional, 1981 Nurcholis Majid, Islam Doktrin dan Peradaban, Jakarta: Paramadina, 2000

Qadri Qal'aji, Tsalatsatun min 'àlam al-Hurriyah, Beirut: Binayatul Wahhad, 1993 
Rasyid Ridha, Tafsîr al-Manâr, Beirut: Dar al-Kutub al-Ilmiah, 1999 Suwito, Sejarah Pemikiran Para Tokoh Pendidikan, Bandung: Angkasa, 2003 Yusuf Hamadi, al-Imâm Muhammad Abduh, Mesir: Maktabah Misr 